\title{
Vägivald loomade vastu: inimene ja koduloom Lõuna-Eesti külas 19. sajandi teisel poolel vallakohtute protokollide näitel
}

Maarja Kaaristo

\begin{abstract}
Teesid
Inimese heaks töötava kodulooma väärtustamine Eesti külaühiskonnas peegeldub suurepäraselt vallakohtute protokollides. Vallakohtud olid alates 18. sajandi lõpust ja 19. sajandil juba valdavalt talurahva esimeseks kohtuinstantsiks, tegu oli esimese ametiasutusega, kuhu talurahvaseisusest inimene oma õigusalaste probleemidega võis pöörduda. Loomade vägivaldselt kohtlemise pärast karistamist Liivimaa talurahvaseadus eraldi ei sätestanud, seega käis loomade vigastamine üldiselt omandi vastu sooritatud kuritegude alla. Artiklis vaadeldakse koduloomade vigastamisega seotud kaebusi erinevate Lõuna-Eesti vallakohtute protokollides. Need jagunevad üldjoontes kaheks: kaebused koduloomade peksmise või vigastamise ning nende tapmise või surma põhjustamise pärast. Loomi peeti eelkõige majandusliku kasu saamiseks, koduloomad olid perele ülalpidamise ja toidu kindlustajad. Seetõttu esinevadki kohtuprotokollides peamiselt lehmad, hobused, sead ja lambad just nende vastu vägivalla tarvitamise pärast oldi üsna agaralt valmis kohtu poole pöörduma.
\end{abstract}

Märksõnad: 19. sajand, karjakasvatus, koduloom, külaühiskond, põllumajandusloomad, vallakohus, vallakohtute protokollid, vägivald

\section{Sissejuhatus}

Nii nagu pole olemas loomade ajalugu ega loomakultuuri (Premack \& Premack 2002: 350-351), pole ka loomade etnoloogiat. Loomade etnoloogia eksisteerib vaid inimese pilgu läbi - missugused on olnud inimeste ja loomade suhted läbi aegade, missuguseid väärtusi, omadusi ja tähendusi on inimene loomadele omistanud.

Ainult inimesed konstrueerivad inimese ja looma suhetest narratiive: alates totemistlikest loomismüütidest kuni teaduslike kä-

http://haldjas.folklore.ee/tagused/nr31/kaaristo.pdf 


\section{Maarja Kaaristo}

sitlusteni, näiteks loomade kodustamise algusest ja selle põhjustest (Ingold 2000: 61).

Kultuuriteadlased huvituvadki antud teema puhul enamasti keskkonna ja inimkultuuri koosmõjust, mida võib nimetada kultuuriökoloogiaks ja defineerida järgmiselt: kultuuriökoloogia uurib inimühiskonna suhteid teiste populatsioonide ja abiootiliste keskkonnateguritega ning nende mõju inimkooslustes aset leidvatele sotsiaalsetele ja kultuurilistele protsessidele (Casimir 1993: 215-216).

Külaühiskonnas elaval eestlasel oli 19. sajandil säilinud eelkõige praktiline suhe koduloomadega: nende ülesanne oli anda liha, piima, villa, teha künnitöid, valvata maja või püüda vähemalt hiiri. Ratsionaalne talupojaühiskond ei tundnud lemmikloomakultuuri. Kuigi lastel võisid olla ja olidki loomad, otsustasid nende saatuse üle siiski täiskasvanud (Torp-Kõivupuu 2004: 48-49). Looma peeti küll hingeliseks olendiks ning eestlasi iseloomustas austav suhtumine loodusesse ja kõigesse elavasse - nii taimedesse kui ka loomadesse (vt nt Linnus 1937: 376-378; Loorits 1990: 44-49; Paulson 1997: 51-102; Valk 1998: 488-499) -, kuid rahvapärase arusaama kohaselt asus looma hing siiski inimese omast astme võrra madalamal: inimesel on hing, tõpral on toss (Loorits 1990: 27; Torp-Kõivupuu 2004: 48).

Inimese heaks töötava kodulooma väärtustamine peegeldub suurepäraselt vallakohtute protokollides. Vallakohtud olid alates 18 . sajandi lõpust ja 19. sajandil juba valdavalt talurahvale esimeseks kohtuinstantsiks, vallakohtu liikmed olid valitud külaelanike endi seast. Niisiis oli just vallakohus esimene ametiasutus, mille poole talupoeg õigusalaste probleemidega sai pöörduda.

Eestlane pidas loomi eelkõige majandusliku kasu saamiseks. Koduloomad olid perele ülalpidamise ja toidu kindlustajad. Seetõttu esinevad kohtuprotokollides peamiselt lehmad, hobused, sead ja lambad - just nende vastu vägivalla tarvitamise pärast oldi valmis kohtusse minema, sageli sama agaralt kui inimese löömise pärast.

\section{Inimese ja looma suhe etnoloogilises perspektiivis}

Etnoloogia kui aine subjekt on inimene. Keerulisem on aga selgitada, kuidas peaks selline inimeseteadus olema konstrueeritud. Ühelt poolt on tegu äärmiselt kitsa, teiselt poolt aga absurdselt laia tee- 
maga. Parim viis inimeseks olemist demonstreerida on läbi aegade olnud tema võrdlemine loomaga (Ingold 2002: 14), looma määratletakse sageli inimese negatsioonina.

Lääne kultuuriruumis on antiikajast tänapäevani mõiste "loom" olnud mõiste "inimene" konstrueerimisel keskseks kategooriaks. Igal põlvkonnal on olnud oma vaatenurk loomadele kui olenditele, kel puudub kõik, mida me peame inimlikuks - näiteks keel, mõistus, intellekt ja moraal. Samas meenutatakse meile üha uuesti, et ka inimesed on loomad - täpsemalt imetajad -, ja parim viis leida inimeseks olemise olemust, on võrrelda teda teiste loomadega (Ingold 2002: 14-15).

Tänapäeval on inimese-looma suhe võrreldes varasemaga oluliselt muutunud. Eriti tugevalt on eestlaste seas muutunud lemmikloomakontseptsioon. Tänapäeval pole lemmikloom mitte niivõrd loom, kuivõrd lemmik: ta on pooleldi inimlikustatud (vt nt Torp-Kõivupuu 2004; Mikkor 2000; Ilomäki 2002: 15-16), pereliige, mis väljendub inimeste muutunud suhtumises lemmikloomadesse.

Lemmikloomadel on eriline seisund inimühiskonnas: neil on nimi, nad elavad koos inimestega, kes sageli kipuvad neile omistama ka moraalseid väärtusi ja omadusi (Ilkka Patoluoto Eläin ihmisten maailmassa, Helsinki 1989, lk 107-108, tsit Ilomäki 2002: $16)$.

Et loomad on olnud juba aastatuhandeid inimkultuuri oluline osa, võib rääkida loomade adapteerumisest või õigemini nende adapteerimisest inimeste kultuuri - see puudutab loomi, kes elavad inimeste seas - kodustatud loomad, lemmikloomad (Lestel 2002: 203). Dominique Lestel räägib koguni inimeste ja loomade hübriidkogukondadest, kus inimesed elavad koos lemmik- ja koduloomadega, kuid parimaks näiteks on tema sõnul ahvidele õpetatav viipe- või muu märgikeel, mille abil nendega suheldakse (Lestel 2002: 204209). Tänapäeva moderniseeruvas ühiskonnas on loomade seisund muutunud, nii näiteks pole nad enam hädavajalikud transpordivahendid (Williams 2003: 106).

Kuigi tuleb nõustuda David ja Ann J. Premackiga, et loomadel pole oma kultuuri, on loomad ometi äärmiselt oluline osa inimkultuurist ja on olnud seda juba tuhandeid aastaid. Seetõttu on ootuspärane, et ka kohtuprotokollidest võib leida märkimisväärselt palju loomadega seotud juhtumeid. 
Maarja Kaaristo

\section{Koduloomade osa eestlaste elus}

Põlluharimine koos karjakasvatusega on olnud eestlaste peamiseks elatusalaks juba aastatuhandeid. Ivar Paulsoni sõnul on see moodustanud

[---] juba eelajaloolise ajastu eesti hõimude ja nende veelgi varasemate eellaste elus ökoloogiliselt tingitud baasi, millel on kujunenud vana eesti rahvakultuur viimase kahe või kolme tuhande aasta kestel (Paulson 1997: 81).

Looduslik keskkond, siinsed ökoloogilised tingimused ja ajaloolised suhted naaberrahvastega on loonud eeldused majanduselu arengule, mis omakorda on mõjutanud ühiskondlikku ja sotsiaalset struktuuri, usundit ning rahvakultuuri. Eesti rahvausk on väga rikas mitmesuguste agraarreligioossete ning maagiliste kujutelmade ja kommete poolest (Paulson 1997: 82). Teiselt poolt on inimeste suhtumist loomadesse mõjutanud ristiusu tulek, mis paigutas nad inimese suhtes otsesesse alluvusse (vt Williams 2003).

Aastatuhandeid oli ka Eestis ainsaks koduloomaks koer. Kuid umbes 2000. aastal eKr kasvatati siin juba kitsi, lambaid, sigu ja veiseid, pronksiajal lisandus hobune. Põlispõllundusega oli koduloomade kasvatamine Eestis selle tekkest peale tihedalt seotud. Kuni 19. sajandi teise pooleni peetigi kariloomi põhiliselt põlluharimise huvides. Loomad andsid põldude väetamiseks vajalikku sõnnikut ja harimiseks tööjõudu (Pärdi 1998: 100).

Kuni 19. sajandi keskpaigani ei muutunud Eesti karjakasvatuses suurt midagi, sest loomi peeti endiselt eelkõige veojõu pärast ja sõnniku saamiseks. Veoloomana peeti Põhja- ja Lääne-Eestis väga palju härgi, Lõuna-Eestis vähem, veoloomana kasutati seal eelkõige hobust. Piimakarja kasvatati Lõuna-Eestis märksa rohkem kui teistes Eesti piirkondades. Lehmal lasti elada väga vanaks - 20aastane lehm polnud mingi haruldus. Nii talude kui ka mõisate karja kuulusid ka lambad, kitsed ja sead. Karjakasvatuse edenemist pärssisid sagedased loomataudid, tuntavalt kärpisid karja ka hundid (Viires 1998: 209-213; vt ka Loorits 2001: 156-170).

Loomade arv oli talu majandusliku kandevõime peamisi näitajaid. Eriti tähtis oli piisava hulga veoloomade olemasolu. Sellest sõltus, kui palju maad suutis talu harida ja kuidas jõuti ära teha mõisa rakmepäevad. Keskmiselt tuli ühes talus pidada 2-3 raken- 
dit. Kui härgi ei jätkunud, pandi härg rakkesse koos lehmaga. Talupoegadel oli kombeks veoloomi üksteisele tasu eest üürida. Peale veoloomade - härgade ja hobuste - kuulusid talukarja tavaliselt ka lehmad ja mullikad, varss või sälg, 2-3 lammast, kitsed, sead ja kodulinnud. Sead olid peamised lihaloomad, lambaid peeti eeskätt villa ja kasukanaha saamiseks (Pärdi 1998: 102).

19. sajandi teisel poolel lisandusid uuendused ka karjakasvatusse. Põllumajandusuuendused - kartuli ja ristikheina kasvatamine, maaparandus ja tõhusamad tööriistad - andsid võimaluse hakata loomi paremini söötma. Loomakasvatuse edenemise põhieeldusteks olid aga talude päriseksostmine ja kaubatootmisele üleminek. Kohalikke loomi hakati mõisakarjades ristama Euroopast pärit tõugudega. Linnade kasv laiendas piimatoodete nõudlust ja loomakasvatuses hakkas rõhuasetus nihkuma piimakarjale. Veiste arv suurenes jätkuvalt 19. sajandi lõpuni, kusjuures taludes peeti neid enam kui mõisates (Pärdi 1998: 102). Niisiis oli just 19. sajandi teiseks pooleks koduloomade majanduslik tähtsus veelgi kasvanud.

Koduloomad olid äärmiselt oluline osa eestlaste elust. Karjakasvatust käsitleb Oskar Looritsa Endis-Eesti elu-olu IV köide, mis sisaldab pärimust karjanõidusest, loomade tapmisest, karjaseelust, ühiskarjatamisest, huntidest, karudest, õitsil käimisest. O. Loorits toob näiteid mitmesugustest karjaga seotud uskumustest: laudas elab karjavaim, kes karjaõnne eest hea seisab (Loorits 2001: 5), hobuseid valvab hobõsõ-elläi (Loorits 2001: 6), ahju all elavate majausside löömine võis põhjustada veise surma (Loorits 2001: 7). Tuntud oli Metsik - karjakaitsja; vastla- või tuhkapäeval kahe küla piiri peal valmistatud õlest kuju (Loorits 2001: 7-8), levinud olid mitmesugused muudki tõrjemaagilised toimingud, mida loomade hea käekäigu tagamiseks tuli sooritada (Forselius 1915: 31-34).

Talupoja sisemise elu- või koduringi moodustasid nn kultuurmaad - tema haritavad põllud, talu, taluõu ja sellel asuvad hooned. Sellesse ringi kuulus ka talupoja perekonnaelu, mis oli alati taluga väga tihedalt seotud. Talupoja sisemisse koduringi kuulusid ka koduloomad - ka nemad arvati "talu" või koguni "pere" hulka (Paulson 1997: 103-104). Niisiis tuleb silmas pidada koduloomade kahedimensioonilist funktsiooni talupere elus. Koduloomad olid ühelt poolt majanduslikult olulised, teiselt poolt aga talupoja sisemise koduringi äärmiselt oluline osa, kuuludes "talusse" niisama 


\section{Maarja Kaaristo}

loomulikult kui talus elavad inimesed, haritud kultuurmaad ning taluõu ja -hooned.

\section{Vallakohtu ajaloost Eestis}

Vallakohtute protokolle uurimisallikana kasutades on oluline arvestada nii üldiselt Eesti ala talupoegade kohtuinstitutsioonide kui ka vallakohtu kui institutsiooni ajalooga.

Esimesed vallakohtud Eesti alal asutati erainitsiatiivil juba 18. sajandi teisel poolel. Vallakohtud muudeti üldiseks 1802. aasta regulatiiviga Iggaüks, kes nouab sannakulik ja öige olla... ning 1804. aasta talurahvaseadustega (vt lähemalt Traat 1980).

Uue vallakorralduse kehtestamisega 1866. aastal vabanesid nii vallavalitsus kui ka vallakohus lõplikult mõisa kontrolli ja eestkoste alt (Peep 1995: 22). Reform lahutas maarahva esmatasandi õigusemõistmise ja kohaliku omavalitsuse ning suurendas viimase pädevust. Pärast 1866. aastat läks suur hulk kohalikke probleeme just vallavalitsuse kompetentsi (Anepaio 1998: 6-7). Vallakohtute pädevusse jäi kohtupidamine ja kohtuotsuste täideviimine tsiviilja väiksemates politseiasjades. Apellatsiooniinstantsiks ja järelevalveasutuseks jäid kuni 1889. aastani kihelkonnakohtud (Hiio 1997: Termin 140, vt ka Kaaristo 2004: 25-28).

Et valdav osa seni vallakohtul lasunud haldusfunktsioone läksid üle vallavalitsusele, saadi keskenduda kohtufunktsiooni täitmisele. Vallakohtud olid seisuslikud kohtud, mille võim laienes ainult talupojaseisusest inimestele. Kuid ka siin olid vallakohtul oma võimupiirid. Suuremad tsiviil- ja kriminaalasjad selle kohtu pädevusse ei kuulunud - need tuli kuni 1889. aasta kohtureformini anda Liivimaa kubermangus sillakohtu lahendada. Vallakohtunike arv sõltus valla suurusest, kuid neid pidi olema vähemalt kolm. Peakohtumeheks sai valida ainult peremeest (Must 1998: 93).

Vene 1864. aasta kohtureformi käigus loodud uus üldkohtute süsteem kehtestati Baltimaades 1889. aasta novembris kohtu-ja talurahvaasutuste reformiga. Kaotati senised seisuslikud kohtud, erandina säilisid talurahvakohtud, apellatsiooniinstantsina loodi ülemtalurahvakohtud (Jegorov 1981: 126). Reformijärgsed vallakohtud arutasid vaid talupojaseisusest isikute vahelisi kohtuasju. Kehtestati uus asjaajamiskord, seniste kronoloogiliste protokolliraamatute asemel seati sisse toimikute süsteem. Vaatamata venestuspolii- 
tikale oli loodud kohtusüsteem varasemaga võrreldes ajakohasem, kiirem ja sõltumatum (Peep 1995: 23).

Pärast kohtureformi läbiviimist jäid vallakohtute pädevusse tsiviilnõudmised kuni 100 rubla väärtuses, nõudmised seoses omandusvõi valdusõiguse rikkumisega, talupoegade pärandvara, eestkoste ja hoolekandega seotud küsimused, lepingute (väärtusega kuni 300 rubla) ja testamentide kinnitamine, süüdistused politseilistes üleastumises, mille puhul kahjukannataja nõudmine ei ületanud 100 rubla, ning valla-ja ülemtalurahvakohtu otsuste täideviimine. ${ }^{1}$ Tsiviilhagid väärtusega alla 15 rubla edasikaebamisele ei kuulunud. Järelevalve kuulus alates 1890. aastast rahukogude kompetentsi, iga-aastase asjaajamise revideerimise viisid läbi ülemtalurahvakohtu eesistujad või jaoskondade rahukohtunikud (Hiio 1997: termin 140). Pärast kohtureformi ei tohtinud vallakohus ihunuhtlust üle 20 vitsalöögi määrata. ${ }^{2}$

\section{Koduloomade vigastamisega seotud kaebused Lõuna-Eesti vallakohtute protokollides}

Loomade löömise, peksmise ja nende vägivaldselt kohtlemise pärast karistamist Liivimaa talurahvaseadus eraldi ei sätesta. Niisiis käis loomade vigastamine üldiselt omandi vastu sooritatud kuritegude alla. ${ }^{3}$ Esimene eestikeelne loomakaitsealane trükis - Tallinna "Elajakaitse-Seltsi" lennuleht Eestirahvale - ilmus Tallinnas 1891. aastal (Tallinna... 1891; siin ja tagapool kirjapilt muutmata, loetavuse huvides on siiski korrigeeritud interpunktsiooni ja asendatud w-täht v-ga, z-täht ts-i või t järel s-iga ja täheühend ij i-ga).

Järgnevalt vaatlen koduloomade vigastamisega seotud kaebusi erinevate Lõuna-Eesti vallakohtute protokollides. ${ }^{4}$ Kõnealused kaebused jagunevad üldjoontes kaheks: kaebused koduloomade peksmise ja vigastamise või nende tapmise või surma põhjustamise pärast. Rohkem leidub haavamise ja peksmisega seotud kaebusi. Vaadeldud kaebustes esinesid järgmised koduloomad: hobune, siga, lehm, lammas, härg, kanad. Kõige enam kaebusi leidus kolme esimesena nimetatud loomaliigi vigastamise kohta - tegu on selgelt majanduslikult seisukohalt kõige vajalikumate ja olulisemate loomadega.

On oluline märkida, et kuigi ka kasside ja koerte kohta võib öel$\mathrm{da}$, et nad osalesid pere majanduselus, on vallakohtute protokollidest lähtuvalt nende tähtsus määratult väiksem. Vaadeldud kohtuprotokollides esinesid koerad üksnes vigastaja, konfliktipõhjusta- 


\section{Maarja Kaaristo}

ja rollis, kordagi ei kaevatud kohtusse koera vigastamise pärast. Ühtki kassidega seotud kohtuasja uuritud kohtuprotokollides ei leidunud.

Kuigi omand oli tähtis ja koduloomi peeti eeskätt majanduslikul eesmärgil, ei saa öelda, et see oleks olnud ainus põhjus, mis pani loomade pärast sedavõrd muret tundma, et nende vigastamise pärast peeti vajalikuks kohtu poole pöördumist. Loomad olid osa taluniku maailmast, kuulusid olemuslikult tema maailmapilti. Niisiis oli koduloomadega kindlasti peale majandusliku ka emotsionaalne side.

\section{Kaebused loomade tapmise kohta}

Tapmisjuhtumid ei olnud loomadega seotud kaebuste seas küll kõige levinumad, kuid siiski tuli ka niisuguseid juhtumeid vallakohtu praktikas ette. Kõnealused juhtumid jagunevad planeeritud, nn tahtlikeks tapmisteks ja õnnetusjuhtumiteks.

Ivan Andrejev Vojeikov kaebas Alatskivi vallakohtus 1878. aastal, et Aleksei Vassiljev Kusov on raputanud oma vilja peale mürgitatud prussakaid ja leiba ning tema viis kana olevat pärast mürgise vilja söömist ära surnud. Kaebealune ütles, et tegi seda sellepärast, et viljavarastest lahti saada. Karistus naabri kanade mürgitamise eest oli aga üpris karm, nimelt pidi Aleksei Kusov maksma 1,5 rubla kahjutasu ja istuma kaks ööpäeva arestis (EAA 1110-1-8 L 23p-24).

Gustav Grosschmidt Joosult kaebas 27. mail 1868 Mari Liivi peale, et viimane on tema sea kiviga surnuks löönud. Tunnistaja Gustav Sõrmus rääkis, et tema tuli sel tseal tagan ja visas kiviga ja leie tsea pikale maha. Mari Liiv pidi surnud sea omanikule ühe rubla kahjutasu maksma (EAA 3385-1-2 L 9).

Kiumas kaebas mõisa tallipoiss Jacob Parmann, et Jüri Vocki naine on tema sea ära kihvtitanud. Nimelt olla siga veidi aega pärast seda, kui Vocki naine teda vaatamas käis, ära surnud. Vocki naine tunnistas, et käis küll siga vaatamas, kuna tahtis seda osta, kuid see oli juba siis haige välja näinud ja siga jäi ostmata. Tunnistaja Liis Tann rääkis veel, et Parmann ise oli arstimise pärast tubliste veevlit andnud seale. Selle peale tühistas kohus Parmanni kaebuse, millega viimane küll rahule ei jäänud, vaid lubas edasi kaevata (EAA 3619-1-1 L 85-86).

Muidugi leidus ka juhtumeid, kui looma surm on põhjustatud kogemata, vähemalt väitsid seda Kahkvas 1866. aasta suvel Peeter Kübara sea ja põrsa tapnud karjused. Karjuste-Peetre poig Kusta, 
Urgava Hendrik ja Vitrik ja Sandi Karli poig Joosep - ülekuulamise käigus selgus, et Peeter Kübara enda poeg oli sea ära tapnud ja seepärast pidi põrsa tapnud Peetri poeg Kusta ainult põrsa eest üks rubla 25 kopikat kahjutasu maksma (EAA 3369-1-1 L 9p-10).

Jüri Bringfelt Alatskivilt kaebas Jonas Taevase peale, nimelt oli viimane põhjustanud tema härja surma. Nimelt olla Taevas Bringfeldi härga lõiganud, mille järel härg verest tühjaks jooksis. Kohtul õnnestus pooled omavahel nii ära lepitada, et Taevas maksis Bringfeltile 12 rubla kahjutasu (EAA 1110-1-8 L 48p).

\section{Kaebused loomade löömise ja peksmise kohta}

Tapmisjuhtumitest märksa enam leidub vallakohtute protokollides loomade vigastamisega seotud kohtuasju. Need kohtuasjad võib tinglikult jagada nelja suuremasse rühma:

- võõras loom leitakse oma maa pealt ja lüüakse teda sealt äraajamise käigus;

- karjus, sulane või teenija vigastab peremehe looma;

- ettekavatsemata vigastamine;

- laenatud looma halvasti kohtlemine.

Loomad, keda hoiti karjuse valve all või laudas, pääsesid mõnikord lahti ja võisid siis minna võõra maa peale. Tihti said sellest alguse konfliktid naabrite vahel, kui naaber võorrast looma liiga tugevasti lõi.

Nii kaebas näiteks Jaan Märtson Uue-Suislepast 19. juulil 1874, et Hans Laituse koer on tema sea väga paljo ära puretanud, nenda et siga selle läbi mito nädalt vigane olnud ja tema teda kodus viljaga toitma pidanud ning selle pääle 2 vakka vilja ära söötnud. Laitus vastas süüdistuse peale, et Märtsoni siga olla tema viljapõllul ringi käinud ja tema pereliikmetele kallale kippunud, niisiis oli Märtson seda siga hullu arvanud olevat ja oma maa pealt ära ajanud, tema koerad polevat seale aga liiga teinud. Kohtumees Hans Laosson vaatas sea samal päeval üle ja leidis, et sellel ei ole midagi viga. Niisiis tunnistati kaebus kehtetuks (EAA 3686-1-2 L 82p-83).

Peremees Peeter Paurson Vastse-Nõost kaebas 14. detsembril 1879 naabri sulase Johan Leppiku peale, et viimane lasi oma peremehe hobusel rehepeksu ajal tema tallu joosta, sest tema hobused olid rehe peksmise tarvis üksteisel sabasse keidetud, siis on see täkk tema hobused lahti hirmutanud ja temal mitmed suitsed katki kiskunud ja ka tema märad ära riknud (EAA 3275-1-5 L 38p). 


\section{Maarja Kaaristo}

Kui Ann Sissas Vastse-Nursist 1871. aastal avastas, et Leno Nilbe tema lehma nuiaga peksab, haaras ta nuia Nilbe käest ära ja hakkas sellega Nilbet ennast peksma. Selle teo eest pidi Ann Sissas Nilbele 3 rubla kahjutasu maksma (EAA 3394-1-3 L 47p).

Üsna suure osa loomadega seotud kaebustest moodustavad peremeeste kaebused sulaste, karjuste jm teenijate peale, et need loomi halvasti kohtlevad. Karjuseid süüdistatakse, et need on lasknud koertel loomadele kallale minna või peksavad oma hoole alla usaldatud loomi. Sulaseid süüdistatakse loomadega halvasti ümber käimises, enamasti nende peksmises.

Näiteks kaebas Jüri Lindok 24. juulil 1867 Kahkvas karjus Peeter Kristuvingi peale, et viimane on lasknud koeral tema lehma niimoodi hammustada, et need penist puretu haavad nü̈̈d mädanevad ja lehm longab nii, et karja ei või minna. Karjus ütles, et tema pole koera lehma kallale ässitanud, kuid ilma koerata ta ka tööd teha ei saa, sest tema hoole all on 80 karilooma. Kohus otsustas, et karjus peab vigastatud lehma enda hoole alla ravile võtma ja oma lehma seniks Jüri Lindokile andma, kuni tema lehm paraneb (EAA 3369-1-1 L 38p).

Sulane Peeter Johanson kaebas Vana-Nursis 29. detsembril 1871 oma peremehe ema peale: nimelt olevat see teda, kui tema loomadele asemeid tegi, nuiaga lönu ja kivviga vissanu. Peremees Peter Welthut vastas vallakohtunikele, et tema ema oli küll sulast noominud, nimelt sellepärast, et sulane ollev ellait hirmsahe pesnu. Kohus mõistis sulasele loomade löömise eest 5 vitsalööki, kuid Peter Welthut pidi oma ema käitumise pärast valla vaestekassasse 1 rubla trahvi maksma (EAA 3394-1-2 L 134p, vt ka Kaaristo 2004: 48).

Vastse-Nursi mõisahärra von Möller süüdistas Peter Harrakut ja Karl Malleust mõisa hobuse nuiaga peksmises (EAA 3394-1-3 L 12p), Carl Saarniit kaebas Ann Sissase peale, et see pigistas tema sea sulu ukse vahele nii, et sial takkast soliko välja ja tsigga tahtse ärrä koolda. Sissas end süüdi ei tunnistanud, kuid tunnistaja Johan Zirrel rääkis, et oli näinud, kuidas Ann Sissas Saarniidu tsea aia vaiele litse (EAA 3394-1-3 L 61, vt ka Kaaristo 2004: 48).

Kaebusi on ka laenuks võetud loomade halvasti kohtlemise pärast. Laenuks võeti eelkõige hobuseid, keda laenati künni jm vedamist nõudvate tööde jaoks. Laenatud loomi, nagu laenuks võetud asjugi, taheti ilmselt viimse võimaluseni kasutada. 1. juunil 1878 kaebas Johan Jakobson Vastse-Nõos, et Margus Laurberg on tema 
hobuse oma sõitmisega väga ära väsitanud, ja nõudis kahjutasu (EAA 3275-1-5 L 11p).

On ka loomade tahtmatu vigastamise juhtumeid. 12. detsembril 1885 tuli Laiuse vallakohtusse Mõra mõisa omanik Aleksander Johannson ja nõudis Peter Mikulini käest kahjutasu vigastatud hobuse eest. Johannson oli 10. detsembril koos Nicolai Lorenzoniga üle Mõra silla läinud, oheliku otsas hobune, keda tahtis oma poja juurde viia. Silla juures tulnud neile kaks Mustvee poissi hobustega järele ja

[---] et küll Nicolai Lorenzon seda hobust tee kõrva vedanud, keeranud Mustvee poiss oma hobusega tee serva ja ree aisa ots läinud tema hobuse seedimise auku 14 tolli pikkuseni ja löönud selle juures veel oma hobust, kui see aisa ots seedimise august välja tulnud, jooksnud sellest august palju verd välja ja arvab, et see hobune selle peale saab ära lõpma (EAA 11202-6 L 26-27).

\section{Kokkuvõte}

Koduloomadesse, kes 19. sajandi teisel poolel majanduselus üha olulisemateks muutusid, suhtuti äärmise hoole ja ettevaatusega. Nii polegi üllatav, et vallakohtusse pöörduti tihti ka loomade peksmise või vigastamise pärast. Mitmel korral oli tegu loomade tahtliku tapmisega, millele süü väljaselgitamise korral järgnes suhteliselt karm karistus: naabri kanade mürgitamise pärast pidi A. Kusov peale trahvi maksmise ka kaks ööpäeva arestis viibima.

Õnnetus ei olnud mitte ainult looma surm - ka looma vigastamine oli tõsine probleem. Loomade peksmised ja muud vigastamised võib tinglikult jagada nelja rühma: võõra looma leidmine oma maa pealt ja tema löömine, peremehe loomi vigastavad sulased ja teenijad, ettekavatsemata vigastamine ning laenatud looma halvasti kohtlemine. Neist kõige levinumad olid kaks esimest.

Kuigi antud kaebuste majanduslik aspekt on väga oluline - enamik vaadeldud kaebustest tegeleb taluperes kõige tähtsamate ja levinumate majandusloomade lehmade, sigade ja hobuste vigastamisega, polnud see kindlasti ainus põhjus, miks loomade vigastamise pärast kohtusse mindi. Loomad kuulusid koos talus elavate inimestega, haritud maade ja taluõuel asuvate hoonetega olemuslikult talu juurde, olles selle lahutamatu osa. 


\section{Maarja Kaaristo}

\section{Kommentaarid}

${ }^{1}$ BWS (Baltimaa Vallakohtu Seadus ja Rahukohtumõistjatelt päälepandavate nuhtluste seadus) 1889, § 1: Liivi, Eesti ja Kuura kubermangu vallakohtud seletavad edaspidi, kunni määrused vallakohtute poolt päälepandavatest nuhtlustest täieste üle saavad vaadatud, asju neist süütegudest, mis 1860. aastal kinnitatud Liivi kubermangu talurahva-seaduste paragrahvides 1033, 1036, 1038, 1040, 1042, 1043, 1049, 1051, 1052, 1054 $1061,1069-1075,1078,1079,1081,1082,1086,1095-1102$ ette ära on tähendatud, järgmisi eeskirju täites (\$§ 2-20).

${ }^{2}$ BWS (Baltimaa Vallakohtu Seadus ja Rahukohtumõistjatelt päälepandavate nuhtluste seadus) 1889, § 3: Asjakohastes paragrahvides 1860. a. kinnitatud Liivi kubermangu talurahva-seaduses määratud ihunuhtlust ei või mitte üle kahekümne löögi mõista.

3 TLS (Lihvandi Talorahva-Seadus 13. Novembril 1860 Kõigekõrgemalt kinnitatud) 1860, § 1062: Iga kogemata ja ettevaatuse puudusest võõra omadusele tehtud kahju peab tegija kahjusaajale äratasuma.

§ 1063: Iga meelega võõra omadusele pettuse ehk väekauba läbi tehtud kahju eest peab sü̈̈llane lugupidamata trahvist, mis alla tema järel tulevate määramiste põhjusel langeb, niisamati kahjusaajale kahju äratasuma.

${ }^{4}$ Enamik artiklis kasutatud allikmaterjalidest on publitseeritud internetis (Türna 2004). Artiklis on kasutatud järgmiste T. Türna publitseeritud vallakohtute protokolle: Eesti Ajalooarhiiv (EAA): fond 1110 (Alatskivi vallakohus), fond 1120 (Laiuse vallakohus), fond 3275 (Vastse-Nõo vallakohus), fond 3369 (Kahkva vallakohus), fond 3385 (Joosu vallakohus), fond 3619 (Kiuma vallakohus), fond 3686 (Uue-Suislepa vallakohus).

\section{Kirjandus ja allikad}

\section{Allikad}

Eesti Ajalooarhiiv (EAA): fond 3394 Nursi vallakohus.

Türna, Tõnis 2004. 1860.-80. aastate Lõuna-Eesti vallakohtute protokollid (http://www.history.ee/vallakohus - 15. detsember 2005).

\section{Kirjandus}

Anepaio, Toomas 1998. Kahe ilma piiril: Võimalikke murdekohti Eesti õigusajaloos ja selle uurimises. Ajalooline Ajakiri 3 (102), lk 5-16.

BWS = Baltimaa Vallakohtu Seadus ja Rahukohtumõistjatelt päälepandavate nuhtluste seadus. Vares, T. (tõlk). Tallinn 1889. 


\section{Maarja Kaaristo}

Casimir, Michael J. 1993. Gegenstandsbereiche der Kulturökologie. Schweizer, Thomas \& Schweizer, Margarete \& Kokot, Waltraud (toim). Handbuch der Ethnologie. Ethnologische Paperbacks. Berlin: Dietrich Reimer Verlag, lk 213-239.

Forselius, Johann 1915. Eestlaste ebausu kombed, viisid ja harjumised. Vanemad Eesti kirjanikud. Tartu: Kuukirja Eesti Kirjandus kirjastus.

Hiio, Ene 1997. Vallakohus. Eesti territooriumiga seotud institutsioonid keskajast kuni 1917. aastani. Tööversioon, I vihik. Tartu: Eesti Ajalooarhiiv.

Ilomäki, Henni 2002. Loomad rahva meeles ja rahvaluule keeles. Jaago, Tiiu \& Kõiva, Mare (toim) Dialoog privaatse ja avaliku elu vahel: Inimese ja keskkonna suhete peegeldus pärimuses: Elektrooniline konverents: Täiendkoolituskursus. Tartu: Eesti Kirjandusmuuseum \& Tartu Ülikool, lk 1318 (http://www.folklore.ee/rl/pubte/ee/cf/dialoog/teema1-2.pdf - 15. detsember 2005).

Ingold, Tim 2000. The Perception of the Environment: Essays on livelihood, dwelling and skill. London \& New York: Routledge.

Ingold, Tim 2002. Humanity and animality. Ingold, Tim (toim). Companion Encyclopedia of Anthropology. Routledge world reference. London \& New York: Routledge, pp 14-32.

Jegorov 1981 = Егоров, Юрий. История государства и права Эстонской ССР: Дооктябрский период (ХІІІ век - окт. 1917 г.). Таллинн: Валгус.

Kaaristo, Maarja 2004. Konfliktid Eesti külaühiskonnas 1868-1911 Nursi vallakohtu sü̈̈teoasjade protokollide näitel. Bakalaureusetöö. Tartu: Käsikiri Tartu Ülikooli etnoloogia õppetoolis.

Lestel, Dominique 2002. Human/animal communications, language and evolution. Torop, Peeter \& Lotman, Mihhail \& Kull, Kalevi (toim). Sign system studies = Труды по знаковым системам = Töid märgisüsteemide alalt 30: 1. Tartu: Tartu University Press, lk 201-212.

Linnus, Ferdinand 1937. Eestlaste aineline kultuur ja rahvausund orduajal. Äratrükk teosest Eesti ajalugu 2, lk 241-382. Tartu: Eesti Kirjanduse Selts.

Loorits, Oskar 1990. Eesti rahvausundi maailmavaade. 2. tr. Tallinn: Perioodika.

Loorits, Oskar 2001. Endis-Eesti elu-olu IV: Lugemispalu karjakasvataja elust. Eesti Rahvaluule arhiivi toimetised = Commentationes Archivi Traditionum Popularium Estoniae 18. Tartu: Eesti Kirjandusmuuseum.

Mikkor, Marika 2000. Minu merisigade elust. Mäetagused: Hüperajakiri 15. Tartu: Eesti Kirjandusmuuseumi folkloristika osakonna rahvausundi 


\section{Maarja Kaaristo}

ja meedia töörühm, lk 152-158 (http://www.folklore.ee/tagused/nr15/ mikkor.htm - 15. detsember 2005).

Must, Kadri 1998. Tori vallakohtu protokollid ajalooallikana. Ajalooline Ajakiri 3 (102), lk 93-108.

Paulson, Ivar 1997. Vana Eesti rahvausk: Usundiloolisi esseid. 2. tr. Tartu: Ilmamaa 1997.

Peep, Viljar 1995. Pilguheit Eesti kohtute ajaloole. Kleio: Ajaloo ajakiri 1 (11), lk 16-26.

Premack, David \& Premack, Ann James. Why animals have neither culture nor history. Ingold, Tim (toim). Companion Encyclopedia of Anthropology. London \& New York: Routledge, pp 350-365.

Pärdi, Heiki 1998. Talumajandus. Viires, Ants \& Vunder, Elle (koost \& toim). Eesti rahvakultuur. Tallinn: Eesti Entsüklopeediakirjastus, lk 73-120.

Tallinna... 1891 = Tallinna "Elajakaitse-Seltsi" lennuleht Eestirahvale 1. Tallinn: s.n.

TLS = Lihvlandi Talorahva-Seadus 13. Novembril 1860 Kõigekõrgemalt kinnitatud Kreutzwald, Friedrich Reinhold (tõlk). Tartu 1963 = Lihvlandi Talorahva Sä̈̈düse-raamat: 13. Nov. 1860 Kõigekõrgembalt kinnitetu. Hurt, Jakob (tõlk). Tartu 1863.

Torp-Kõivupuu, Marju 2004. Risti peale kirjutas: Ühel papil oli peni...: Eesti loomakalmistukultuurist. Mäetagused: Hüperajakiri 25. Tartu: Eesti Kirjandusmuuseumi folkloristika osakonna rahvausundi ja meedia töörühm \& MTÜ Eesti Folkloori Instituut, lk 47-76 (http://www.folklore.ee/ tagused/nr25/loomakalmistud.pdf - 15. detsember 2005).

Traat, August 1980. Vallakohus Eestis: 18. sajandi keskpaigast kuni 1866. aasta reformini. Tallinn: Eesti Raamat.

Valk, Ülo 1998. Inimene ja teispoolsus Eesti rahvausundis. Viires, Ants \& Vunder, Elle (koost \& toim). Eesti Rahvakultuur. Tallinn: Eesti Entsüklopeediakirjastus, lk 485-511.

Viires, Ants 1998. Liiklus ja vedu. Viires, Ants \& Vunder, Elle (koost \& toim). Eesti rahvakultuur. Tallinn: Eesti Entsüklopeediakirjastus, lk 207-227.

Williams, Cassandra D. 2003. Liberating the Enlightenment: How a Transformed Relationship with Animals Can Help Us Transcend Modernity. Religious Education 98: 1, lk 95-107. 